\title{
Teaching Traditional Values in the Social Studies Classroom through Storytelling
}

\author{
Michael Bamidele Adeyemi \\ Department of Languages and Social Sciences Education, University of Botswana \\ Gaborone, botswana \\ E-MAIL: adeyemim@mopipi.ub.bw
}

Accepted: November 10, 2011 Published: January 02, 2012

Doi:10.5296/ijld.v2i1.1216 URL: http://dx.doi.org/10.5296/ijld.v2i1.1216

\begin{abstract}
This paper examined the use of storytelling in the effective teaching of traditional values at a junior secondary school in Botswana. The national values of Botswana were briefly presented and specifically linked with an aspect of hard work in producing the effective citizen. The story of a lazy student was used to elicit questions and answers from a Form One social studies class. An analysis of the students' qualitative responses indicated progressive low to high order responses. This is interpreted to mean that storytelling is a powerful tool in the teaching-learning process. A number of conclusions were made which included: the enhancement of learning through storytelling; the use storytelling to elicit high order thinking; and the use of small groups for the acquisition of knowledge and decision making. Based on the findings and conclusions, it was recommended that teachers should adapt their methods of teaching to specific teaching/learning situation; that storytelling should be emphasized as a technique of teaching in the syllabus or the curriculum; and the need to encourage further research on the power or efficacy of storytelling in the teaching-learning situation.
\end{abstract}

Keywords: Values, Storytelling, teaching, learning, efficacy, social studies, Botswana

\subsection{Introduction}

The essence of any society is to develop in all spheres of life that is; socially, economically, psychologically, politically and technologically. For this reason, societies strive to have values for the enhancement of the overall progress of their individual members (Adeyemi, 2010). In the pre-modern societies, values education was used to shape the citizens to conform to the way 
of life and social ethics of the specific society. The use of stories in the teaching of values formed an important technique of transmitting societal norms from generation to generation. Values education is closely related to citizenship education. For instance, education for citizenship emerged in Greece during the classical era. Aristotle, like Plato before him, saw education as a means of shaping the community into what it should be. This includes moulding individuals into physically fit, good, loyal and responsible citizens. The ancient ideas on the practices of citizenship education continued after the demise of the Greek and Roman states into many indigenous and modern societies all over the world. The indigenous system of education has its objectives of creating a better society in which to live in. The Western mode of education also has its complimentary objectives of developing a better society. As a result, countries have their philosophies or values enunciated in their national policies to guide the type of societies deemed best for their citizens (Adeyemi, Adeyinka, 2002).

Social studies is a subject that is value-laden. Although American in origin, it is interpreted as a type of citizenship education with a strong dose of ethical training for character and the overall development of citizens (Lichona, 2004). This interpretation is no different from the original aims of social studies in African countries. The curriculum of social studies, and specifically at the junior secondary level in Botswana contains many values that should be taught in the classroom. Many strategies have been advocated to achieve cognitive, psychomotor and the affective objectives while teaching social studies in the junior secondary classroom.

Generally, social studies is taught to learners with the use of two methods: the transmission and the problem solving methods. Categorized under the transmission methods are such techniques as the lecture and recitation, which involve learning by heart and with little participation on the part of the learners. On the other hand, the problem solving method includes discussion, group work, research exercises, panel discussions and activity-related tasks which enable learners to be active in the teaching-learning process. Of the many techniques used to teach values in the classroom, storytelling seems to be given a prominent role in imparting knowledge to learners. Depending on the teacher, it can combine aspects of the techniques of both the transmission and the problem solving methods to bring about effective learning.

\subsection{Aim of this paper}

This paper seeks to highlight the importance of storytelling in the teaching of social values in an African country, Botswana.

\subsection{Objectives}

The objectives of this paper are:

To tell a story during a social studies lesson to illustrate an aspect (hard work) of the value of botho, in a Botswana junior secondary school class; and

To evaluate the effects of the storytelling on attitudes of the students. 


\subsection{Values Of Botswana As Enunciated In Its National Principles And Vision 2016}

Following its independence from Britain, Botswana has had education sector reviews with a view to making its education relevant to societal contexts. Subsequent to the reviews, educational policies were developed. The policies preach values that can contribute to the development of effective citizens. Two education policies, the National Policy on Education (Republic of Botswana, 1977), and the Revised National Policy on Education (Republic of Botswana, 1994) were formulated to make the education system relevant to fulfill its aim of improving the lives of its citizens. The Report of the Botswana's National Commission on Education, otherwise known as Education for Kagisano (Republic of Botswana, 1977, 24) spells out the four national principles that form the basis for education as:

- Democracy;

- Development;

- Self-reliance; and

- Unity.

In 1997, the Botswana Government published what is popularly known as Vision 2016 as an additional document to augment the national principles as values deemed necessary for the development of the country. The values complement the national principles and envision the effective preparation of students for life, citizenship and the world of work. Such an individual will have botho. In other words, the individual will be well-rounded, well-mannered, courteous and disciplined as well as realise his or her full potential both as an individual and as a part of the community to which he or she belongs (Presidential Task Group, 1997, 2). The value of botho has profound implications for teachers in their quest to develop in students the attributes of the 'whole' citizens who can contribute generally to the development of the society. Related to Education for Kagisano is Vision 2016. This Vision talks of an education in Botswana that would promote seven pillars or values such as:

- An educated, informed nation;

- A prosperous, productive and innovative nation:

- A compassionate, just and caring nation;

- A safe and secure nation;

- A moral and tolerant nation;

- An open, democratic and accountable nation;

- A united and proud nation (Presidential Task Group, 1997, 5-12).

From the afore-going, it is apparent that the role of schools in the realisation of the dreams listed above cannot be over-emphasised. Therefore, how can storytelling be used to teach an idea of botho (hard working) as a value in the junior secondary school setting?

\subsection{Teaching an Aspect of the Value a 'Moral and Tolerant Nation' Through Story Telling}

As indicated earlier, there are seven pillars or values highlighted in the Vision 2016 of Botswana. One of them is the promotion of "a moral and tolerant nation". For the citizen of a 
country to be well-rounded, well-mannered, courteous and disciplined, such a citizen must be morally upright and tolerant. In a nutshell, the citizen in question must not be lazy, but hardworking. To simplify the story, hard-work as a micro-value has been purposively chosen from the gigantic value of moral uprightness and tolerance. Laziness, which is literally the opposite of hard-work, brings about all sorts of ill-behaviour. As a result of laziness, a citizen may become a truant in school, a drug-addict, a miscreant or bad citizen in general. One of the aims of the Ten-Year Social Studies Programme (which encompass the aims of Junior Secondary Education) is the acquisition of knowledge and understanding of society, appreciation of their culture including languages, traditions, songs, ceremonies, customs, social norms and a sense of citizenship (Republic of Botswana, 1996). To be able to achieve the aim, a citizen must be hard-working. A pertinent question related to good moral then arises: how can a social teacher teach a junior secondary class how to be hard-working through storytelling?

\subsection{Method}

The writer sought the permission of a junior secondary school in Gaborone, the capital of Botswana to teach a topic for a double period (80 minutes) to Form One students. For our international readers, the Form One junior secondary students were about 13 years of age and they were 31 in the class. In other words, they can be said to be $8^{\text {th }}$ graders in the American setting. The Botswana school system is divided into seven years of primary education, three years of junior secondary education, and two years of senior secondary education before embarking on the tertiary level of education. The Form One class was purposively chosen because of the familiarity of the class teacher with the writer. The following steps were taken at the beginning and at the end of the lesson.

Step 1: The actual class teacher introduced the writer to the class as a friend of the school who would tell them a story.

Step 2: A rapport was established with the Form One junior secondary school students.

Step 3: I introduced myself and told them I would tell them an interesting story on "The Evil Effects of Laziness". At this stage, the students were very attentive and were curious to listen to the story.

Step 4: I posed a question: Have you been told a story on the concept of laziness before? Many of the students answered in the negative. I informed them that today's story would be very rewarding and gainful. The students seemed attentive and eager to listen to the story. I narrated the story as found below.

\section{The Story}

Once upon a time, there was a lazy Form One junior secondary school student. The student was always late to school daily. He would not listen to the class teacher. He hated English language, mathematics, science, social studies and fine art. He was always disruptive in class. He often beat up students who were not as physically strong as him. In fact, he was a bully. He was a terror. He would not study both at school and at home. He would not attend to any 
homework or assignments given to the class by the teacher. He liked to listen to music and television programmes at a public place after school hours. In fact, he was also addicted to alcohol. After 15 years, most of his classmates graduated from various tertiary institutions, while those who did not have the opportunity to attend tertiary institutions were excelling in their chosen careers. This student became a miscreant and eventually became a taxi driver through the help of a philanthropist. At an airport to pick up a Very Important Personality (VIP) to a destination, the lazy student-turned taxi driver discovered that the VIP he was transporting was his classmate at the junior secondary school. Upon recognition of the VIP as a former classmate at school, he started crying and lamenting saying: 'Had I known, I would have worked harder while at school, I now realize I was lazy’.

At the end of the story, the students were divided into five groups and requested to find answers to some questions, among others, as:

Would you want to be in the same boat as the lazy student? Why and why not?

What advice would you have given the lazy student if you were one of his classmates?

What lessons can you draw from this story?

What advice would you give the lazy student now that he is a frustrated taxi driver?

Answers to questions during the storytelling exercise were written on the chalkboard for

evaluation as to the 'power' or 'efficacy' of storytelling to teach an aspect of moral value.

\subsection{Evaluating the Effects Of Storytelling On Attitudes Of Junior Secondary Students}

Simply put, evaluation is the measurement of an outcome. The objective was to analyse the answers in qualitative terms by the students as to the effects of the story on their attitudes concerning the lazy student after the story. This falls under the measurement of values or the measurement of the affective domain. Some of the qualitative answers or comments or questions provided by the students unedited included:

Question: Would you want to be in the same boat as the lazy student?

Answers: Most recurring answers from the groups: Our group would not want to be in the same boat with the lazy student because he messed up his life.

All members of our group would want to be technocrats in various fields. Some of us would want to be politicians, some medical doctors, some university Vice-Chancellors, and so on.

Question: What advice would you have given the student if you were one of his classmates?

Answers: Why not work hard?

Do your assignments.

Why can't you stop coming late to school?

Stop beating up other students.

Question: What lesson can you draw from the story?

Answers: Our group concludes that it does not pay to be lazy. 
Our own group submits that it is better to 'strike the iron when it is hot'.

We think that we should remember the children of whom we are and so work very hard.

Question: What advice would you give the lazy student now that he is a frustrated taxi-driver? Answers: Our group agrees that taxi driver should take his job more seriously because he can contribute positively to the society.

Our group has identified a millionaire transporter in town. If serious, the frustrated taxi driver can be a millionaire also.

Our group identifies success with responsibility.

Our group would advise him not to combine alcoholism with business.

\section{Other Related Questions and Answers}

In addition to the group answers provided above, pertinent questions and answers from the students are provided also unedited below:

I am curious: was the lazy student punished when he was misbehaving in school?

We are interested in the social status of the parents of the lazy student? Did he come from a dysfunctional family?

Was the taxi driver confident while at school?

What was the character of those who were close to the bully? Did they try to help him?

We can imagine that there must be a sort of Welfare Officers that should have talked to the lazy boy while at school. Did any help, such as from a psychologist available to the truant?

We worked as a group to conclude that we need philanthropists in the society to help such bad cases.

The Ministry of Education should devise means by which waste of talents should be avoided in the society. Since the boy was an effective taxi driver, it was possible he became a better citizen, given the guidance in time.

\subsection{Analysis of Students' Answers, Comments And Question}

At this juncture, it is necessary to examine some of the comments or questions from Table 1 provided. First and foremost, the story adopts two methods of transmission and the problem solving. The story was narrative in nature and this connotes a lecture transmission method. The division of the students into five groups suggests students working together to find answers to problems. Many of the story teller's questions were probing and so elicited higher response answers.

Table 1: An Evaluation of Teacher's Story and Students' Responses

\begin{tabular}{|l|l|l|l|}
\hline Method & Technique & Tasks/Words & $\begin{array}{l}\text { High/Low } \\
\text { Order } \\
\text { Response }\end{array}$ \\
\hline Transmission & $\begin{array}{l}\text { Narrative } \\
\text { storytelling }\end{array}$ & $\begin{array}{l}\text { Introduction of self and the story } \\
\text { Sequential history of the lazy student } \\
\text { Arresting the interest of the students } \\
\text { Creating an atmosphere of empathy }\end{array}$ & $\begin{array}{l}\text { Low } \\
\text { Order }\end{array}$ \\
\hline Problem & Division $\quad$ into & Probing the curiosity of students & High Order \\
\hline
\end{tabular}




\begin{tabular}{|c|c|c|}
\hline Solving & $\begin{array}{l}\text { groups to find } \\
\text { answers } \\
\text { to questions }\end{array}$ & $\begin{array}{l}\text { Probing questions from the teacher } \\
\text { and students on whether the lazy } \\
\text { student was punished or not, e. g. } \\
\text { Was the student allowed to see a } \\
\text { psychologist } \\
\text { or a welfare officer? } \\
\text { Did he come from a dysfunctional } \\
\text { family? } \\
\text { Some students were already } \\
\text { recommending solutions to the } \\
\text { Ministry of Education. } \\
\text { Students } \\
\text { Relating proverbs to the predicament } \\
\text { of the lazy student e.g. 'Strike the iron } \\
\text { when it is hot'. } \\
\text { Students provide the way forward to } \\
\text { the predicament of the taxi driver }\end{array}$ \\
\hline
\end{tabular}

I am curious, was the lazy student punished when he was misbehaving in school". The word 'curiosity' connotes a situation where the learner wants to know more about a phenomenon. There seems to be a thirst for more information about the lazy student. The intention of the learner to know whether the lazy student was punished or not while at school might mean that the student might not have been a nuisance later in future were he punished or corrected at the appropriate time. Further, the learners asked about the character of those who were close to the lazy student while at school. This question also bothers on the assumption that some of his friends or peers might have been bad in behaviours themselves and so contributed to his fate. It was an indication that the last student received no counseling. The learners specifically questioned whether the last student had access to welfare officers and psychologists while at school who could have helped him reshape his life. They queried the fact that as an effective taxi driver, he would also have been effective in other spheres of life were he given the necessary attention at the appropriate time. In other words, the larger society might have been contributed to the predicament of the lazy student.

A significant question from the students also focused on the type of family of the lazy student. A dysfunctional family might not be able to help the situation of the lazy student. The learners thought there was a correlation between the behaviours of parents and their offspring. This supports the African belief which says: 'like parents like children'. To a large extent, the learners believe that socio-economic status affects the behaviours of children. In fact, some of the learners were agitated to ask whether the taxi driver was confident while at school. This might mean a relationship exists between the confidence level of learners and future career. In addition, the learners recognized the important of working together. Research has found that working together significantly contributes to learning outcomes. 
Some conclusions can be drawn from the answers, comments and questions of the Form One students. These include: The capability of storytelling to enhance learning by students: if properly used, storytelling is a useful tool in arresting students' attention and thereby contributing to effective learning. This conclusion tallies with the view of Kiflik, Mullan (2007) who identified storytelling as an effective means of bringing about learning in the classroom. Progressive low to high order thinking: From Table 1, students were able to think along the low order and through curiosity ordered their thinking level to the high order by being able to analyze situations. This progressive ordering is in line with the conclusion of Cangelosi, Whitt (2006) who advocated for high order thinking from simple to complex situations. The use of small groups to work together eases acquisition of knowledge and decision making: Working in groups to find solutions to problems is very effective in learning. Just as Kelly (2007) has found, outcomes have been achieved using groups in the teaching-learning settings.

\section{Recommendations}

\section{Adaptation of Methodology to the Teaching/Learning Situation}

As much as there are many teaching techniques, no one technique is enough to bring about effective learning. In this situation, a combination of techniques was used in the teaching-learning process. They include the transmission and the problem solving techniques. Therefore, teachers should endeavour to use the techniques best suited to a situation.

\section{Entrenchment of Storytelling in the Curriculum/Syllabus of Subjects}

In the writing of syllabuses and programmes, many techniques and methods of teaching are often recommended to enhance the learning of phenomena. It is hereby recommended that storytelling can be effectively used to solicit both low and high order responses in the Bloom's (1968) taxonomy of educational objectives. The pre-service and in-service education of teachers should further equip them with the relevant techniques of designing questions requiring high order responses in the taxonomy: synthesis, analysis and evaluation, particularly when storytelling is used in the classroom.

\section{Further Research on Storytelling}

Research may also be necessary to examine among others, the best way of using storytelling to teach values. Storytelling has been found to be very effective in the learning process at elementary and secondary school settings. It may be necessary to further investigate the efficacy or the powerful effects of the use of storytelling vis-à-vis other techniques of teaching in the African environment (Bowering, Legget, Hui, 2007). 


\section{References}

Adeyemi, Michael B. (2010). Social Studies as Pedagogy for Effective Citizenship. An Inaugural Lecture delivered at the University of Botswana, Gaborone: Centre for Continuing Education.

Adeyemi, Michael B. and Adeyinka, Augustus A. (2003). The Principles and Content of African Traditional Education, In Educational Philosophy and Theory, Vol. 35, No. 4, 425-440.

Bowering, Margaret., Legget, Bridget M., and Hui, Leng. (2007). Opening up Thinking: Reflections on Group Work in a Bilingual Postgraduate Program. In. International Journal of Teaching and Learning in Higher Education, Vol.19, No. 2, 105-116.

Blooms, Benjamin. S. (1968). Taxonomy of Educational Objectives: Handbook 1, Cognitive Domain, New York; Kckay Company Inc.

Cangelosi, Pamela, R., and Whitt, K. J. (2006). Teaching through Storytelling: An exemplar. In International Journal of Nursing Education Scholarship, Vol. 3, No. 1, 201-210.

Combs, M. A. and Beach, John, D. (1994). Stories and Storytelling: Personalizing the Social Studies. The Reading Teacher, Vol. 47, No. 6, 464-471.

Hussain, Safaat., Anwar, Saeed., and Majoka, Muhammad. I. (2011). Effects of Peer Group Activity-related Learning on Students' Academic Achievement in Physics at Secondary Level. International Journal of Academic Research, Vol. 3, No. 1, 940-944.

Jusoh, Zuraini, (2009). The Effectiveness of Storytelling Technique in Teaching and Learning Narrative Writing in the Malay Language, Unpublished Masters Thesis, University of Putra Malaysia.

Kagoda, Alice. M. (2009). Teaching and Learning Geography through Small Group Discussions.

Current Research Journal of Social Sciences, Vol. 1, No. 2, 27-32.

Kelly, Phil. (2007). Achieving Desirable Group-Work Outcomes through the Group Allocation Process, Team Performance Management, Vol. 14, Nos. 1/2, 22-38.

Kriflick, Lynda, and Mullan, Judy. (2007). Strategies to improve Student Reaction to Group Work, Journal of University Teaching and Learning Practice, Vol. 4 No.1, 13-27.

Lichona, Tom, (2004). Character Matters, New York: Touchstone 
Presidential Task Group for a Long Term Vision for Botswana (1997). Long Term Vision for Botswana - Towards Prosperity for All, Gaborone: Government Printer.

Republic of Botswana (1994). Revised National Policy on Education, Gaborone: Government Printer.

Republic of Botswana (1977). Education for Kagisano. Report of the National Commission on Education, Gaborone: government Printer.

Republic of Botswana (1996). Three-Year Junior Secondary Syllabus (Social Studies). Gaborone: Department of Curriculum and Evaluation, Ministry of Education. 